For citation: Betti, G., Karadag, M. A., Sarica, O. \& Ucar, B. (2017). Regional Differences in Equivalence Scales in Turkey. Ekonomika regiona [Economy of Region], 13(1), pp. 63-69

doi 10.17059/2017-1-6

UDC: 332

JEL Classification: D12, I32, C51

\author{
G. Betti ${ }^{\text {a) }}$, M. A. Karadag ${ }^{\text {b) }}$, O. Sarica ${ }^{\text {b) }}$, B. Ucar ${ }^{\text {b) }}$ \\ a) University of Siena (Siena, Italy; e-mail: gianni.betti@unisi.it) \\ b) Turkish Statistical Institute (Ankara, Turkey)
}

\title{
REGIONAL DIFFERENCES IN EQUIVALENCE SCALES IN TURKEY ${ }^{1}$
}

Equivalence scales have a crucial role in poverty measurement. For Turkey, there are no available up-todate equivalence scales, representing Turkish data. There were no efforts for calculation of equivalence scales at the regional level. The aim of the paper is to calculate and propose an equivalence scale for Turkey and estimate regional differences. Besides the models with Engel method, different equivalence scales were estimated by Almost Ideal Demand System. The results of the first model of AIDS approach composed of 5 age groups, is proposed for Turkey, but for simplicity the results of the second AIDS model could be used as well. In this model, the equivalence scale for Turkey is calculated as 0.65 for each additional adult after the first one and 0.35 for each child. For regional equivalence scales, we use two methods and comare the results. In the first one, regressions were run for each region separately and in the second one, dummy variables introduced. The highest difference in the results of the two methods was observed in Istanbul region. The findings for the regional scales are less reliable as the household size is bigger. This limitation is due to the relatively small size of the data sets. Having surveys with higher sample sizes would enable better results. After getting the results some conclusions could be drawn especially with regard to child cost differences among regions. It was expected to have higher costs for children in poorer regions and the regional results have confirmed this hypothesis.

Keywords: equivalence scales, child costs, regional equivalence scales, Engel curve, regional differences, almost ideal demand system, poverty measurement, poverty indicators, Turkey, HBS, NUTS

\section{Introduction}

Equivalence scales used in the calculation of poverty indicators have a remarkable significance. In Turkey, an equivalence scale suggested by World Bank and OECD scales are used for the calculation of different types of poverty indicators. There is a need for an equivalence scale, which is particular to Turkish data. This paper aims to calculate an equivalence scale from Turkish data and propose to be used in the calculation of poverty indicators in Turkey. A second objective of the paper is to calculate equivalence scales at the regional level. This is realized for NUTS1 regions for Turkey.

Equivalence scales are used to enable comparisons of monetary indicators (i. e. income and consumption expenditure among different household types. There is no common determination on how to calculate equivalence scales. In the literature, there are many studies on the classification and construction of equivalence scales. Among others, Buhmann et al. [1] and Hagenaars et al. [2], Engel [3], Barten [4], Gorman [5], Pollak and Wales [6], Lewbel [7], Deaton and Muellbauer [8] Ray [9], Charlier [10] Pendakur [11], Kot [12], Betti and

\footnotetext{
${ }^{1}$ (c) Betti G., Karadag M. A., Sarica O., Ucar B. Text. 2017.
}

Lundgren [13], Dudek [14], Muellbauer and Van de Ven [15], Balli and Tiezzi [16], Majumder and Chakrabarty [17], Rojas [18] are some of the prominent studies in literature.

In Turkey, so far, there are two efforts for the calculation of equivalence scales. The first is by Sengul [19], using 1994 Household Consumption Expenditure Survey data. Besides this out-of-date study, there is another study Sengul and Cafri [20], which was performed by local data which is not representative for Turkey. A recent article by Betti et. al. [21] also deals with equivalence scales with regard to poverty measurement in Turkey, but the calculation of equivalence scales is not in the scope of this paper.

The paper is composed of 6 sections. After the present introduction, Section 2 describes the data set. In Section 3, several equivalence scales are estimated. In section 4, poverty headcount ratios are compared according to different national equivalence scales. Section 5 presents the results of equivalence scales estimated at the regional level. Finally, Section 6 concludes the paper.

\section{The data set}

Household budget survey is one of the important sources which provides information on so- 
cio-economic structures, standards of living, and consumption patterns of the households, and which is used to test the viability of the socio-economic policies being implemented.

In Turkey, for the measurement of absolute poverty, Household Budget Survey is used. The national poverty line is computed using data from this survey.

This survey aims to reveal consumption patterns of households. With this survey, it is possible to produce information on consumption habits, types of consumption expenditures and diversity of spending for goods and services according to socio-economic characteristics of households, employment status of household members, the total income of households, and source of income. The sample size is around 13000 households for 2012 Household Budget Survey. The non-response rate was $24.6 \%$.

For calculation of equivalence scales with Engel method which take into the regions consideration, data for three years, 2010, 2011 and 2012 respectively, are pooled and reweighted. With this new dataset, calculations at the NUTS1 level are made possible. For estimations with other Engel models, for consistency, also the three years pooled dataset was used.

The pooled data set only serves for increasing the sample size, and for having estimates significant at the regional level. Pooling more years (i.e. 5 years) comes up with drawbacks because the data is less homogenous (the gap is too large from the first and last period). The years 2010-2012 are specifically chosen because these years are more homogenous in terms of consumption pattern in Turkey.

\section{Empirical analysis: equivalence scales}

The first model estimated by using HBS, is based on the food ratio method, which refers to Van Ginneken [22]:

$$
\ln F_{i}=a+b \ln X_{i}+c \ln N_{i}+e_{i},
$$

where $F$ is the expenditure for food (COICOP category 1), $X$ is the total consumption expenditure and $\mathrm{N}$ stands for family size. Engel's [3] law states that the household's standard of living varies inversely with the food ratio. By making use of this law, the economies of scale $\varepsilon$ (for $d(F / X)=0$ ) can be derived:

$$
\varepsilon=\frac{\partial \ln X}{\partial \ln N}=\frac{c}{1-b} .
$$

The model estimated by making use of HBS data, points out a rather high elasticity value, which is equal to 0.6486 . This confirms that both
OECD-modified scales and the 'official scales' are too flat for Turkey.

Moreover, in order to observe the effect of adults and children separately, Engel curves are also estimated applying the model given in Deaton and Muellbauer [23] which is an extension of Working-Leser equation:

$$
w_{f}=\alpha+\beta \ln \frac{x}{n}+\gamma_{1} n_{1}+\gamma_{2} n_{2}+\varepsilon,
$$

where $w_{f}$ is food share of households, $x$ is total expenditure, $n$ is household size, $n_{1}$ is the number of children (age $\leq 13$ ) and $n_{2}$ is the number of adults (age $>13)$. In order to get regression parameter estimates, we use pooled Household Budget Survey data for years of 2010-2012, total sample size is 29987. For Turkey as a whole, summary results of regression model (3) are given below,

$$
\begin{gathered}
\hat{w}_{f}=0.90934-\underset{(0.00099)}{0.09860} \ln \frac{x}{n}- \\
-\underset{(0.00067)}{0.01936 n_{1}-\underset{(0.00056)}{0.00948} n_{2},} \\
R^{2}=0.2184 .
\end{gathered}
$$

In addition, the model above that contains extra-regional dummies (12 regions) is re-estimated, where dummies are introduced in the model, in a way that changes the only level of the regression line. Results for model (3) with regional dummies is given below,

$$
\begin{gathered}
\hat{w}_{f}=0.81470-\underset{(0.00101)}{0.08842} \ln \frac{x}{n}- \\
-\underset{(0.00066)}{0.01872} n_{1}-\underset{(0.00055)}{0.00919} n_{2}, \\
R^{2}=0.2516 .
\end{gathered}
$$

In order to convert Engel curves to equivalence scales, the procedure in Deaton and Muellbauer [23] is followed. A household that contains one adult is chosen as a reference and average cost of extra adult and child to one-adult-households are estimated as in Table 1. If extra cost of adult/child is estimated less than 0.20 , they are accepted as 0.20 .

As seen in Table 1, estimated equivalence scales from both models are so close to each other. Therefore, for further analysis, we chose the estimates from the model with regional dummies as proposed equivalence scales for Turkey based on Engel method since it takes into account regional differences.

The third estimated model is the AIDS introduced in Section 2, where socio-demographic variables have been introduced using the Ray [9] Price Scaling method: $\ln \left(\frac{x}{m(p, z)}\right)$ where $m(p, z)$ is defined in two different methods: 
Average cost of extra adult/ child to the household that contains one adult

\begin{tabular}{|l|c|c|c|c|}
\hline \multirow{2}{*}{ Extra } & \multicolumn{2}{|c|}{ National: 1. Without regional dummies } & \multicolumn{2}{c|}{ National: 2. With regional dummies } \\
\cline { 2 - 5 } & Adult & Child & Adult & Child \\
\hline 1. Person & 0.82 & 0.64 & 0.8 & 0.62 \\
\hline 2. Person & 0.66 & 0.39 & 0.64 & 0.34 \\
\hline
\end{tabular}

Table 2

AIDS_PS1 estimates (p-values are reported in parentheses)

\begin{tabular}{|c|c|c|c|c|c|c|c|c|}
\hline & Group 1 & Group 2 & Group 3 & Group 4 & Group 5 & Group 6 & Group 7 & Group 8 \\
\hline \multirow[b]{2}{*}{$\alpha_{i}$} & 0.683647 & 0.184612 & -0.10025 & 1.076195 & -0.05145 & -0.14386 & -0.49385 & -0.04196 \\
\hline & $(<.0001)^{* \star *}$ & $(0.0005)^{* * *}$ & $(0.0266)^{*}$ & $(<.0001)^{* * *}$ & $(-0.3777)$ & $(0.0088)^{* *}$ & $(<.0001)^{* * *}$ & $(-0.3746)$ \\
\hline \multirow{2}{*}{$\beta_{i}$} & -0.08222 & -0.0062 & 0.018153 & -0.1028 & 0.017655 & 0.027693 & 0.092197 & 0.019151 \\
\hline & $(<.0001)^{* * *}$ & $(<.0001)^{* * *}$ & $(<.0001)^{* * *}$ & $(<.0001)^{* * *}$ & $(<.0001)^{* * *}$ & $(<.0001)^{* \star *}$ & $(<.0001)^{* \star *}$ & $(<.0001)^{* * *}$ \\
\hline \multirow[b]{2}{*}{$\gamma_{1, i}$} & 0.061685 & 0.158941 & -0.16394 & 0.162041 & 0.027813 & -0.05531 & 0.124862 & -0.19236 \\
\hline & $(-0.5698)$ & $(-0.145)$ & $(-0.1277)$ & $(-0.1283)$ & $(-0.7954)$ & $(-0.6077)$ & $(-0.2429)$ & $(-0.0708)$ \\
\hline \multirow{2}{*}{$\gamma_{2, i}$} & -0.04451 & -0.01736 & 0.063819 & -0.10603 & 0.020423 & -0.0556 & 0.042222 & -0.03041 \\
\hline & $(-0.4716)$ & $(-0.7812)$ & $(-0.2993)$ & $(-0.0821)$ & $(-0.7389)$ & $(-0.366)$ & $(-0.4888)$ & $(-0.6177)$ \\
\hline \multirow[b]{2}{*}{$\gamma_{3, i}$} & -0.06038 & 0.03992 & -0.05221 & 0.041478 & 0.018752 & -0.01544 & 0.076056 & 0.059883 \\
\hline & $(-0.2541)$ & $(-0.4549)$ & $(-0.3224)$ & $(-0.4272)$ & $(-0.7206)$ & $(-0.7693)$ & $(-0.1451)$ & $(-0.2508)$ \\
\hline \multirow[b]{2}{*}{$\gamma_{4, i}$} & 0.056561 & 0.079578 & -0.05467 & -0.31606 & -0.04284 & 0.115286 & -0.10978 & 0.116032 \\
\hline & $(-0.6077)$ & $(-0.4731)$ & $(-0.6182)$ & $(0.004)^{* * *}$ & $(-0.6949)$ & $(-0.293)$ & $(-0.3134)$ & $(-0.2852)$ \\
\hline \multirow[b]{2}{*}{$\gamma_{5, i}$} & 0.02711 & -0.006 & 0.022179 & -0.00429 & 0.091453 & -0.0359 & 0.032722 & -0.05311 \\
\hline & $(-0.6914)$ & $(-0.9306)$ & $(-0.7439)$ & $(-0.9493)$ & $(-0.1772)$ & $(-0.597)$ & $(-0.627)$ & $(-0.4299)$ \\
\hline \multirow[b]{2}{*}{$\gamma_{6, i}$} & -0.01017 & -0.03253 & 0.083027 & 0.038321 & -0.03472 & 0.017581 & -0.11832 & 0.059088 \\
\hline & $(-0.8744)$ & $(-0.6163)$ & $(-0.1939)$ & $(-0.5457)$ & $(-0.5857)$ & $(-0.7839)$ & $(-0.062)$ & $(-0.3509)$ \\
\hline \multirow[b]{2}{*}{$\gamma_{7, i}$} & -0.03402 & -0.07584 & 0.048035 & 0.104342 & -0.08305 & 0.023131 & 0.072286 & -0.00182 \\
\hline & $(-0.779)$ & $(-0.535)$ & $(-0.6895)$ & $(-0.3833)$ & $(-0.4882)$ & $(-0.8475)$ & $(-0.5464)$ & $(-0.9878)$ \\
\hline \multirow{4}{*}{$\gamma_{8, i}$} & -0.02755 & -0.05584 & 0.028784 & 0.009447 & 0.032004 & 0.022539 & -0.07416 & 0.035576 \\
\hline & $(-0.6183)$ & $(-0.3162)$ & $(-0.6003)$ & $(-0.8625)$ & $(-0.5587)$ & $(-0.6817)$ & $(-0.1736)$ & $(-0.5122)$ \\
\hline & $\hat{\tau}_{1}=0.287662$ & $\hat{\tau}_{2}=0.420127$ & $\hat{\tau}_{3}=0.49914$ & $\hat{\tau}_{4}=0.586792$ & $\hat{\tau}_{5}=0.712319$ & & & \\
\hline & $(<.0001)^{* * *}$ & $(<.0001)^{* * *}$ & $(0.0009)^{* * *}$ & $(<.0001)^{* * *}$ & $(<.0001)^{* * *}$ & & & \\
\hline
\end{tabular}

*** Parameter significant at $99 \%$ level.

** Parameter significant at $95 \%$ level.

* Parameter significant at $90 \%$ level.

1) $m(p, z)=\sum_{i=1}^{5} \tau_{i} z_{i} m(p, z)=\sum_{i=1}^{5} \tau_{i} z_{i}$, where $z_{i}$ are the number of persons in each one of the following five age groups: children aged $0-5$; children aged $6-13$; children aged $14-17$; adults aged 1864 ; elderly aged $65+$.

2) $m(p, z)=\sum_{i=1}^{2} \tau_{i} z_{i} m(p, z)=\sum_{i=1}^{2} \tau_{i} z_{i}$, where $z_{i}$ are the number of persons in each one of the following two age groups: children aged $0-13$; adults aged $14+$.

For estimating the AIDS model, the 12 consumption expenditure classes, of the COICOP classification, are collapsed into nine groups. This has been necessary since some components show a very small share of total consumption (below 4-5\%), so that the corresponding parameters in the AIDS model may have a too large sampling variance. The first five groups and the last group are not aggregated. On the other hand, group 6, 10 and culture section of group 9 are aggregated and new group 6 is created; group 7 and 8 are aggregated and new group 7 is created and recreation section of group 9 and group 11 are aggregated and new group 8 is created ${ }^{1}$.

The findings from the AIDS models are as follows Table 2 and 3.

On the basis of the results from the estimated models by Engel method and by AIDS models, here we propose a new equivalence scale for Turkey (Table 4) as well as its alternative (5), based on the findings as reported in detail in Table 2 and Table 3.

\footnotetext{
${ }^{1} 1$. food and non-alcoholic beverages; 2 . alcoholic beverages, tobacco; 3. clothing and footwear; 4 . housing, water, electricity, gas and other fuels; 5 . furnishings, household equipment and routine maintenance of the house; 6 . health; 7. transport; 8. communication; 9. recreation and culture; 10. education; 11. restaurants and hotels; 12 . miscellaneous
} 
Table 3

AIDS_PS2 estimates (p-values are reported in parentheses)

\begin{tabular}{|c|c|c|c|c|c|c|c|c|}
\hline & Group 1 & Group 2 & Group 3 & Group 4 & Group 5 & Group 6 & Group 7 & Group 8 \\
\hline \multirow[b]{2}{*}{$\alpha_{i}$} & 0.677908 & 0.199144 & -0.10202 & 1.116985 & -0.06209 & -0.15706 & -0.52387 & -0.03391 \\
\hline & $(<.0001)^{* * *}$ & $(0.0002)^{* * *}$ & $(0.0243)^{* *}$ & $(<.0001)^{* * *}$ & $(-0.287)$ & $(0.0042)^{* * *}$ & $(<.0001)^{* * *}$ & $(-0.4756)$ \\
\hline \multirow{2}{*}{$\beta_{i}$} & -0.08155 & -0.00816 & 0.018412 & -0.1084 & 0.019105 & 0.029498 & 0.096344 & 0.018095 \\
\hline & $(<.0001)^{* \star *}$ & $(<.0001)^{* * \star}$ & $(<.0001)^{* * *}$ & $(<.0001)^{* * *}$ & $(<.0001)^{\star * \star}$ & $(<.0001)^{* * \star}$ & $(<.0001)^{\star * \star}$ & $(<.0001)^{* \star \star}$ \\
\hline \multirow[b]{2}{*}{$\gamma_{1, i}$} & 0.07302 & 0.16978 & -0.15692 & 0.160824 & 0.0297 & -0.0598 & 0.11327 & -0.19609 \\
\hline & $(-0.5068)$ & $(-0.1245)$ & $(-0.1503)$ & $(-0.1365)$ & $(-0.7847)$ & $(-0.5839)$ & $(-0.2959)$ & $(-0.0692)$ \\
\hline \multirow[b]{2}{*}{$\gamma_{2, i}$} & -0.04404 & -0.0172 & 0.064033 & -0.10585 & 0.021859 & -0.05752 & 0.044348 & -0.03135 \\
\hline & $(-0.4756)$ & $(-0.7828)$ & $(-0.2968)$ & $(-0.082)$ & $(-0.7208)$ & $(-0.3489)$ & $(-0.4664)$ & $(-0.6062)$ \\
\hline \multirow[b]{2}{*}{$\gamma_{3, i}$} & -0.06281 & -0.04217 & -0.05372 & 0.041698 & 0.018078 & -0.01413 & 0.078016 & 0.060834 \\
\hline & $(-0.2362)$ & $(-0.4306)$ & $(-0.3094)$ & $(-0.4255)$ & $(-0.7307)$ & $(-0.7887)$ & $(-0.1356)$ & $(-0.2441)$ \\
\hline \multirow[b]{2}{*}{$\gamma_{4, i}$} & 0.069537 & 0.090999 & -0.04689 & -0.31673 & -0.03634 & 0.104608 & -0.11464 & 0.109309 \\
\hline & $(-0.5274)$ & $(-0.4111)$ & $(-0.6686)$ & $(0.0039)^{* \star \star}$ & $(-0.739)$ & $(-0.3394)$ & $(-0.2918)$ & $(-0.3133)$ \\
\hline \multirow[b]{2}{*}{$\gamma_{5, i}$} & 0.024976 & -0.0078 & 0.020922 & -0.00424 & 0.090034 & -0.03369 & 0.032824 & -0.0518 \\
\hline & $(-0.7143)$ & $(-0.9098)$ & $(-0.7577)$ & $(-0.9497)$ & $(-0.1836)$ & $(-0.6195)$ & $(-0.6256)$ & $(-0.4409)$ \\
\hline \multirow[b]{2}{*}{$\gamma_{6, i}$} & -0.0136 & -0.0355 & 0.08098 & 0.038456 & -0.03666 & 0.020677 & -0.11744 & 0.060993 \\
\hline & $(-0.8322)$ & $(-0.5837)$ & $(-0.2043)$ & $(-0.5435)$ & $(-0.5642)$ & $(-0.7466)$ & $(-0.0635)$ & $(-0.3347)$ \\
\hline \multirow[b]{2}{*}{$\gamma_{7, i}$} & -0.0458 & -0.08642 & 0.040948 & 0.105039 & -0.08833 & 0.032045 & 0.077932 & 0.00397 \\
\hline & $(-0.706)$ & $(-0.4802)$ & $(-0.7338)$ & $(-0.3809)$ & $(-0.4616)$ & $(-0.7903)$ & $(-0.5163)$ & $(-0.9735)$ \\
\hline \multirow{4}{*}{$\gamma_{8, i}$} & -0.03037 & -0.05866 & 0.027002 & 0.009865 & 0.032146 & 0.02287 & -0.0701 & 0.036134 \\
\hline & $(-0.5846)$ & $(-0.2949)$ & $(-0.6248)$ & $(-0.8572)$ & $(-0.5589)$ & $(-0.6788)$ & $(-0.2006)$ & $(-0.5079)$ \\
\hline & $\hat{\tau}_{1}=0.638122$ & $\hat{\tau}_{2}=0.353734$ & & & & & & \\
\hline & $(<.0004)^{* \star \star}$ & $(<.0001)^{* * *}$ & & & & & & \\
\hline
\end{tabular}

${ }^{* * *}$ Parameter significant at $99 \%$ level.

** Parameter significant at $95 \%$ level.

* Parameter significant at $90 \%$ level.

\section{Estimation of headcount ratio}

In this section, poverty headcount ratios are calculated with three different equivalence scales to detect the effect of using different scales and highlight its policy implication. The three equivalence scales that are compared are, the modified OECD scales, where each additional adult has a weight of 0.5 and every child has a weight of 0.3 ; the equivalence scale suggested to Turkstat by World Bank, where all adults have a weight of 1 and children have a weight of 0.9 and economies of scale is also used with a power of 0.6 ; and the new equivalence scales calculated and proposed in this paper, in which each additional adult has a weight of 0.65 and every child has a weight of 0.35 . For estimating, the headcount ratio, official absolute poverty lines published by Turkish Statistical Institute (TURKSTAT) are used. Poverty lines are derived by inflating the latest published poverty lines with consumer price index.

The results demonstrated in Table 6 indicate that the use of new equivalence scales has an increasing effect on poverty headcount ratio especially for more populated households. The magnitude of the economies of scale suggested by World Bank has a decreasing effect on poverty
Table 4

Proposed equivalence scales for Turkey

\begin{tabular}{|l|c|}
\hline \multicolumn{1}{|c|}{ Category } & Scale \\
\hline First adult of age 18-64 & 1.00 \\
\hline Any additional adult of age 18-64 & 0.60 \\
\hline First adult of age 65 or more & 0.70 \\
\hline Any additional adult of age 65 or more & 0.50 \\
\hline Children of age 14-17 & 0.50 \\
\hline Children of age $6-13$ & 0.40 \\
\hline Children of age $0-5$ & 0.30 \\
\hline
\end{tabular}

Table 5

Alternative proposed equivalence scales for Turkey

\begin{tabular}{|l|c|}
\hline \multicolumn{1}{|c|}{ Category } & Scale \\
\hline First adult of age 14 or more & 1.00 \\
\hline Any additional adult of age 14 or more & 0.65 \\
\hline Any additional child of age $0-13$ & 0.35 \\
\hline
\end{tabular}

headcount ratio as the household size increases, as expected because of the exponential function it comprises. On the other hand, headcount ratios calculated according to modified OECD scale and new scale indicate similar values. At this point, we argue that the new equivalence scale is preferable to the one suggested by the World Bank because it brings about similar results with the modified 
Table 6

Poverty headcount ratios by equivalence scale and household size

\begin{tabular}{|r|c|c|c|}
\hline \multirow{2}{*}{$\begin{array}{c}\text { Household } \\
\text { Size }\end{array}$} & \multicolumn{3}{|c|}{ Equivalence Scale } \\
\cline { 2 - 4 } & OECD(modified) & World Bank & New \\
\hline 1 & 17.1 & 15.9 & 14.9 \\
\hline 2 & 11.9 & 11.1 & 11.7 \\
\hline 3 & 9.4 & 7.9 & 9.7 \\
\hline 4 & 11.4 & 10.0 & 12.1 \\
\hline $5+$ & 35.2 & 26.6 & 38.2 \\
\hline $\begin{array}{r}\text { Total } \\
\text { Population }\end{array}$ & 20.8 & 16.5 & 22.2 \\
\hline
\end{tabular}

OECD scale which has common use within the European Union countries and thus enables international comparisons at European level. We also argue that use of new equivalence scale is preferable to modified OECD scale because it's calculated from Turkish data and thus it's peculiar to the situation in Turkey.

\section{Regional differences in equivalence scales}

Equivalence scales for each NUTS1 region of Turkey are estimated in order to examine regional differences. To do so, two different approaches are utilised. Firstly, we run regression model (3) for each region separately. Secondly, we add regional dummy variables to all slope parameters in the model (3) and estimate scales for each region. In order to avoid dummy variable trap, eleven dummy variables are created. Dummy variables are introduced to slope parameters in a way given below:

$$
\begin{gathered}
w_{f}=\alpha+\beta \ln \frac{x}{n}+\gamma_{1} n_{1}+\gamma_{2} n_{2}+ \\
+\beta_{1}\left(D_{1} \ln \frac{x}{n}\right)+\beta_{2}\left(D_{2} \ln \frac{x}{n}\right)+\ldots+\beta_{12}\left(D_{11} \ln \frac{x}{n}\right)+ \\
+\gamma_{11}\left(D_{1} n_{1}\right)+\gamma_{12}\left(D_{2} n_{1}\right)+\gamma_{112}\left(D_{11} n_{1}\right)+ \\
\left.+\gamma_{21}\left(D_{1} n_{2}\right)+\gamma_{22}\left(D_{2} n_{2}\right)+\gamma_{212} 2\right)+\varepsilon .
\end{gathered}
$$

Table 7 gives estimated Engel scales of the first method in which parameters of Model 1 are estimated separately for each region. It is observed that there are noticeable differences among regions regarding the cost of extra adults and children. At this point, it should be noted that values higher than 1 are valued as 1 and values less than 0.20 are valued as 0.20 in order to have more plausible values instead of figures that are extraordinarily high or low due to the scarcity of observations at hand. As the number of adults and children increase the number of observations in the model decrease to very small amounts especially at the regional level and particularly for regions with a smaller number of observations. Therefore, the equivalence scales at the regional level should be approached and evaluated carefully, knowing that the reliability of the calculated figures is lower as the number of adults and children increase in the household.

Table 8 gives estimated Engel scales of the second approach where parameters of the model that contain regional dummies in all slope parameters are used. According to results, the cost of extra adults and children are much higher in regions TRA, TRB and TRC which are relatively less developed regions. It can be concluded that more developed regions indicate less cost of extra adults and children.

When regional equivalence scales derived in both approaches are compared, the biggest difference belongs to Istanbul (TR1) where the cost of extra children and adults are estimated lower in the second approach. On the contrary, the cost of adults in Batı Karadeniz (TR8), Doğu Karadeniz (TR9) and Güney Doğu Anadolu (TRC) are estimated higher in the second approach. For the rest of the regions, there aren't significant differences

\begin{tabular}{|c|c|c|c|c|c|c|c|c|c|c|c|c|}
\hline & \multicolumn{2}{|c|}{ TR1: Istanbul } & \multicolumn{2}{|c|}{$\begin{array}{l}\text { TR2: Batı } \\
\text { Marmara }\end{array}$} & \multicolumn{2}{|c|}{ TR3: Ege } & \multicolumn{2}{|c|}{$\begin{array}{l}\text { TR4: Doğu } \\
\text { Marmara }\end{array}$} & \multicolumn{2}{|c|}{$\begin{array}{l}\text { TR5: Batı } \\
\text { Anadolu }\end{array}$} & \multicolumn{2}{|c|}{ TR6: Akdeniz } \\
\hline & Adult & Child & Adult & Child & Adult & Child & Adult & Child & Adult & Child & Adult & Child \\
\hline 1. Person & 0.91 & 0.77 & 0.64 & 0.43 & 0.72 & 0.48 & 0.74 & 0.55 & 0.84 & 0.57 & 0.83 & 0.59 \\
\hline 2. Person & 0.83 & 0.58 & 0.39 & 0.20 & 0.49 & 0.20 & 0.54 & 0.26 & 0.71 & 0.28 & 0.68 & 0.31 \\
\hline 3. Person & 0.74 & 0.42 & 0.20 & 0.20 & 0.32 & 0.20 & 0.37 & 0.20 & 0.59 & 0.20 & 0.55 & 0.20 \\
\hline \multirow[t]{3}{*}{ 4+ Person } & 0.68 & 0.30 & 0.20 & 0.20 & 0.20 & 0.20 & 0.23 & 0.20 & 0.48 & 0.20 & 0.43 & 0.20 \\
\hline & \multicolumn{2}{|c|}{$\begin{array}{l}\text { TR7: Orta } \\
\text { Anadolu }\end{array}$} & \multicolumn{2}{|c|}{$\begin{array}{l}\text { TR8: Batı } \\
\text { Karadeniz }\end{array}$} & \multicolumn{2}{|c|}{$\begin{array}{l}\text { TR9: Doğu } \\
\text { Karadeniz }\end{array}$} & \multicolumn{2}{|c|}{$\begin{array}{c}\text { TRA: Kuzey } \\
\text { Doğu Anadolu }\end{array}$} & \multicolumn{2}{|c|}{$\begin{array}{c}\text { TRB: Orta } \\
\text { Doğu Anadolu }\end{array}$} & \multicolumn{2}{|c|}{$\begin{array}{l}\text { TRC: Güney } \\
\text { Doğu Anadolu }\end{array}$} \\
\hline & Adult & Child & Adult & Child & Adult & Child & Adult & Child & Adult & Child & Adult & Child \\
\hline 1. Person & 0.70 & 0.55 & 0.76 & 0.56 & 0.83 & 0.58 & 0.97 & 0.81 & 1.00 & 1.00 & 0.87 & 0.75 \\
\hline 2. Person & 0.46 & 0.25 & 0.56 & 0.27 & 0.67 & 0.28 & 0.94 & 0.64 & 1.00 & 1.00 & 0.76 & 0.55 \\
\hline 3. Person & 0.29 & 0.20 & 0.41 & 0.20 & 0.55 & 0.20 & 0.91 & 0.5 & 1.00 & 1.00 & 0.66 & 0.38 \\
\hline 4+ Person & 0.20 & 0.20 & 0.27 & 0.20 & 0.43 & 0.20 & 0.88 & 0.38 & 1.00 & 1.00 & 0.56 & 0.25 \\
\hline
\end{tabular}
regarding the method in use.

Table 7

Estimated Engel equivalence scale for each region (data separation method) 
Table 8

Estimated Engel equivalence scale for each region (using dummies)

\begin{tabular}{|c|c|c|c|c|c|c|c|c|c|c|c|c|}
\hline & \multicolumn{2}{|c|}{ TR1: Istanbul } & \multicolumn{2}{|c|}{$\begin{array}{l}\text { TR2: Batı } \\
\text { Marmara }\end{array}$} & \multicolumn{2}{|c|}{ TR3: Ege } & \multicolumn{2}{|c|}{$\begin{array}{c}\text { TR4: Doğu } \\
\text { Marmara }\end{array}$} & \multicolumn{2}{|c|}{$\begin{array}{l}\text { TR5: Batı } \\
\text { Anadolu }\end{array}$} & \multicolumn{2}{|c|}{ TR6: Akdeniz } \\
\hline & Adult & Child & Adult & Child & Adult & Child & Adult & Child & Adult & Child & Adult & Child \\
\hline 1. Person & 0.78 & 0.64 & 0.65 & 0.42 & 0.70 & 0.48 & 0.72 & 0.55 & 0.79 & 0.54 & 0.86 & 0.60 \\
\hline 2. Person & 0.60 & 0.37 & 0.40 & 0.20 & 0.48 & 0.20 & 0.50 & 0.24 & 0.60 & 0.24 & 0.73 & 0.33 \\
\hline 3. Person & 0.44 & 0.20 & 0.21 & 0.20 & 0.29 & 0.20 & 0.33 & 0.20 & 0.46 & 0.20 & 0.62 & 0.20 \\
\hline \multirow[t]{3}{*}{ 4+ Person } & 0.31 & 0.20 & 0.20 & 0.20 & 0.20 & 0.20 & 0.20 & 0.20 & 0.33 & 0.20 & 0.51 & 0.20 \\
\hline & \multicolumn{2}{|c|}{$\begin{array}{c}\text { TR7: Orta } \\
\text { Anadolu }\end{array}$} & \multicolumn{2}{|c|}{$\begin{array}{c}\text { TR8: Batı } \\
\text { Karadeniz }\end{array}$} & \multicolumn{2}{|c|}{$\begin{array}{l}\text { TR9: Doğu } \\
\text { Karadeniz }\end{array}$} & \multicolumn{2}{|c|}{$\begin{array}{c}\text { TRA: Kuzey } \\
\text { Doğu Anadolu }\end{array}$} & \multicolumn{2}{|c|}{$\begin{array}{c}\text { TRB: Orta } \\
\text { Doğu Anadolu }\end{array}$} & \multicolumn{2}{|c|}{$\begin{array}{c}\text { TRC: Güney } \\
\text { Doğu Anadolu }\end{array}$} \\
\hline & Adult & Child & Adult & Child & Adult & Child & Adult & Child & Adult & Child & Adult & Child \\
\hline 1. Person & 0.71 & 0.56 & 0.85 & 0.57 & 0.96 & 0.59 & 0.98 & 0.82 & 1.00 & 0.98 & 0.98 & 0.86 \\
\hline 2. Person & 0.48 & 0.26 & 0.71 & 0.28 & 0.93 & 0.30 & 0.96 & 0.66 & 0.99 & 0.95 & 0.97 & 0.72 \\
\hline 3. Person & 0.31 & 0.20 & 0.59 & 0.20 & 0.89 & 0.20 & 0.95 & 0.52 & 0.98 & 0.93 & 0.94 & 0.61 \\
\hline 4+ Person & 0.20 & 0.20 & 0.49 & 0.20 & 0.85 & 0.20 & 0.92 & 0.41 & 0.98 & 0.91 & 0.93 & 0.51 \\
\hline
\end{tabular}

\section{Conclusions}

This paper was constructed to propose a suitable equivalence scale for Turkey. For this purpose, four different equivalence scales were computed. Three were calculated by Engel method, the first disregarding child-adult difference, one taking the effect of regions into consideration and the other one not taking this into consideration. The result for the first was too flat while the other two gave similar values. For this reason, only one of these equivalence scales, the one which takes into consideration child-adult difference and the effect of regions, was used in the forthcoming analysis. Two other equivalence scales were computed by AIDS model. The first was composed of five different age groups where the second one was composed of only two groups as child and adult where the definitions for child and adult were in line with OECD and EUROSTAT definitions. In this respect, the result of the first AIDS model is proposed for Turkey as it encompasses more detailed information. On the other hand, the result of the second AIDS model could be used as well for simplicity and if deemed necessary to have two age groups in line with OECD scales. According to this equivalence scale, first adult has the value of 1 , any subsequent adult has the value of 0.65 and any children have the value of 0.35 .

Comparing poverty headcount ratios showed that use of economies of scale suggested by World Bank created a significant difference. Use of this scale causes underestimation of poverty, especially for bigger households. Although the results indicate similar values for modified OECD scale and the new scale, we propose the use of new scales, which represents Turkish data better because it's calculated from it.

The second objective of the paper was to look at the regional differences in equivalence scales. For this, two different methods were used and the results were presented. At the regional level, the reliability of figures is lower due to the smaller number of observations as the household size gets bigger with additional adults or children. All the same, the study produced equivalence scales at the regional level which can be used in studies for analyses of poverty figures at the regional level.

The results at regional level also confirmed the expectations about regional differences in child costs. The expectation was to observe higher costs for children in poorer regions. The regional equivalence scales gave the opportunity to confirm this hypothesis.

\section{References}

1. Buhmann, B., Rainwater, L., Schmauss, G., \&. Smeeding, T. (1988). Equivalence Scales, Well-being, Inequality, and Poverty: Sensitivity Estimates Across Ten Countries Using the Luxembourg Income Study (LIS) Database. Review of Income and Wealth, 34, 115-142.

2. Hagenaars, A. J. M., de Vos, K. \& Zaidi, M. A. (1994). Poverty Statistics in the late 1980s: Research in micro-data. Office for Official Publications of the European Community, Luxembourg, 415.

3. Engel, E., (1895). Die Lebenskosten Belgischer Arbeiter-Familien Früher and Jetzt. International Statistical Institute Bulletin, 9, 1-74.

4. Barten, A. P. (1964). Family Composition, Prices and Expenditure Patterns. Econometric Analysis for National Economic Planning. Ed. by Peter E. Hart, Gordon Mills, and John K. Whitaker. London: Butterworths (for Colston Res. Soc.), 320. 
5. Gorman, T. (1976). Tricks With Utility Functions. Essays in Economic Analysis: Proceedings of the 1975 AUTE Conference, Sheffield. Ed. by M. J. Artis and A. R. Nobay. Cambridge: Cambridge University Press, 292.

6. Pollak, R. A. \& Wales, T. J. (1981). Demographic Variables in Demand Analysis. Econometrica, 49, 1533-1551.

7. Lewbel, A. (1985). A Unified Approach to Incorporating Demographic or Other Effects into Demand Systems. Review of Economic Studies, 52, 1-18.

8. Deaton, A. \& Muellbauer, J. (1980). An almost ideal demand system. The American Economic Review, 70, 312-326.

9. Ray R. (1983) "Measuring the cost of children: an alternative approach" Journal of Public Economics, vol. 22, pp. 89-102.

10. Charlier, E. (2002). Equivalence scales in an intertemporal setting with an application to the former West Germany. Review of Income and Wealth, 48, 99-126.

11. Pendakur, K. (2005). Semiparametric estimation of lifetime equivalence scales. Journal of Applied Econometrics, 20, 487-507.

12. Kot, S. (2014). Inter-temporal equivalence scales based on stochastic indifference criterion: the case of Poland. Paper presented to the IARIW 33rd General Conference, Rotterdam, August 2014. Retrieved from: http://www.iariw.org/papers/2014/KotPaper.pdf (date of access: 11.03.2016).

13. Betti, G. \& Lundgren, L. (2012). The impact of remittances and equivalence scales on poverty in Tajikistan. Central Asian Survey, 31(4), 395-408.

14. Dudek, H. (2014). Do shares of food expenditure in the European Union converge? A country-level panel data analysis. Economic Computation and Economic Cybernetics Studies and Research, 48(4), 245-260.

15. Muellbauer, J. \& Van de Ven, J. (2004). Equivalence Scales and Taxation: A Simulation Analysis. In Dagum C., Ferrari G. (Eds). Household Behaviour, Equivalence Scales, Welfare and Poverty. New York: Springer, 85-106.

16. Balli, F. \& Tiezzi, S. (2010). Equivalence scales, the cost of children and household consumption patterns in Italy. Review of Economics of the Household, 8(4), 527-549.

17. Majumder, A. \& Chakrabarty, M. (2010). Estimating Equivalence Scales Through Engel Curve Analysis. In: Basu B., Chakravarty S.R., Chakrabarti B.K., Gangopadhyay K. (Eds). Econophysics and Economics of Games, Social Choices and Quantitative Techniques. Springer: New York, 241-251.

18. Rojas, M. (2014). Household Equivalence Scale. Encyclopaedia of Quality of Life and Well-Being Research, $2947-2950$.

19. Sengul, H. (2006). Equivalent Scale on Food Consumption in Turkey. Journal of Applied Sciences, 6, 1172-1175.

20. Sengul, S., \& Cafri, R. (2010). Yoksulluk Ölçümünde Engel Ve Rothbarth Eşdeğerlik Ölçekleri. Ç.Ü. Sosyal Bilimler Enstitüsü Dergisi. Cilt 19, Sayı 2, Sayfa 47-61.

21. Betti, G., Karadag, M. A., Sarica, O. \& Ucar, B. (2016). How to Reduce the Impact of Equivalence Scales on Poverty Measurerement: Evidence from Turkey. Social Indicators Research. DOI: 10.1007/s11205-016-1335-0.

22. Van Ginneken, W. (1982). Generating Internationally Comparable Income Distribution Data: Evidence from the Federal Republic of Germany (1974), Mexico (1968) and the United Kingdom (1979). The Review of Income and Wealth, 28, 365-379.

23. Deaton, A., \& Muellbauer, J. (1986). On Measuring Child Costs: With Applications to Poor Countries. Journal of Political Economy, 94, 720-744.

\section{Authors}

Gianni Betti - PhD in Applied Statistics, Professor, Department of Economics and Statistics, University of Siena (Piazza San Francesco, Siena, Tuscany, 531007, Italy; e-mail: gianni.betti@unisi.it).

Mehmet Ali Karadag - PhD, Expert, Turkish Statistical Institute (114, Necatibey, Ankara, Cankaya, 06420, Turkey; e-mail: makaradag@gmail.com).

Ozlem Sarica - Expert, Turkish Statistical Institute (114, Necatibey, Ankara, Cankaya, 06420, Turkey; e-mail: ozlemsarica@tuik.gov.tr).

Baris Ucar - PhD Candidate, Expert, Turkish Statistical Institute (114, Necatibey, Ankara, Cankaya, 06420, Turkey; e-mail: ucarbaris1@hotmail.com). 